\title{
PEMANFAATAN TEKNOLOGI KOMPUTER DI UPU PERPUSTAKAAN UNIVERSITAS GADJAH MADA
}

\author{
The Use of The Computer Technology at The Main Library \\ of Gadjah Mada University
}

Uminurida Suciati", Partini* ${ }^{* *}$ Isbandiyah HS.**

\begin{abstract}
The quality of the library will impact the quality of the students and the research. Main Library of Gadjah Mada University as a unit of the information service is expected to be able to provide the information which can fulfill the user needs and also can be a place to process information retrieval. In addition, the available of the computer technology service can motivate the user to visit library more often.
\end{abstract}

Research method which is used is mixture research i.e descriptive qualification and survey. The respondents who are interviewed consisted of SO, S1,S2, S3, lecturer, researcher, staff of UGM and the users outside of UGM. Whereas, some methods which are used were observation, interviewed and distributed the questionnaire to 200 users. Analysis is done after interpreting the result of interviews and the survey which the data analysis and the process of the data collecting were observed at the same time. The 3 flow models of Miles and Huberman in Bungin is used i.e data reduction, data presentation, and verification.

The result of the research of the computer technology use in Gadjah MadaLibrary, as follows: it provides positive impact to the user to visit the library, it shows $94 \%$ of the user search the reference materials which are used by the lecturer including papers, lecturing materials, thesis, result of the research and result of the laboratory, it is expected the implementation of the computer technology in the library can change the catalog card to cut the long queue, it shows $75 \%$ of the user know very well how to use the computer optimally. The user al ways follow the technological trend of the computer, and have the enthusiasm high to read. Collection of The Main Library of Gadjah Mada University in the reality shows $75 \%$ have fulfilled the user requirement, and so do sum up the adequate computer enough, but require to be added its amount. The service of access internet in this research is inclusive of quickly and better compared depend to library of faculty. The user used the SIPUS program very easy, because its program is easy to use. The staff giving services attitude of the user very fulfilled and the system of services circulation use one card system, so that facilitate made easy for staff and the user.

Key Words : the computer technology-user need-internet services

* Perpustakaan UGM

** Fakultas Ilmu Sosial dan IImu Politik UGM

*** FakuItas Ilmu Sosial dan Ilmu Politik UGM

Perkembangan ilmu pengetahuan dan teknologi dari hari ke hari meningkatkan volume informasi yang harus disimpan, sedangkan daya tampung secara fisik perpustakaan tidak bertambah. Kesulitan mengelola dan mengakses informasi di masa yang akan datang akan menimbulkan dampak positif dan negatif bagi perpustakaan itu sendiri. Akan tetapi menurut Toffler (1990: 1) dewasa ini volume informasi yang dicetuskan/dihasilkan dapat dialihkan, walaupun kecepatan membengkaknya informasi yang berkembang sebagai salah satu dampak dari peradaban gelombang ketiga yang disebut era globalisasi informasi. Adanya pengalihan informasi dari media fisik ke media digital saat ini memungkinkan informasi dapat diakses melalui sarana komputer dan perangkat kelengkapannya.

Perpustakaan merupakan salah satu dari 
sekian banyak institusi yang memberikan layanan jasa, tidak lepas dari penggunaan komputer dalam hampir semua kegiatan. Komputer merupakan salah satu dari sekian banyak peralatan yang dibuat manusia guna meningkatkan efisiensi kerja, produktivitas dan tingkat kehidupan manusia (Hadi, Umar, 2004). Pemanfatan teknologi informas $i$ di perpustakaan dengan komputer sebagai komponen utamanya lazim di sebut automasi (Sulistyo-Basuki, 1993:36). Sistem automasi meneakup penanganan pekerjaan rutin perpustakaan (library house keeping) dan penelusuran informasi (information retrieval). Untuk itu perpustakaan tergantung pada jaringan komputer sebagai alat-alat disediakan untuk mengakses ke sumber daya informasi lokal dan internasional.

Untuk memenuhi kebutuhan akan informasi UPU Perpustakaan UGM harus memberdayakan sumber daya yang ada yang berupa sarana fisik dari gedung, koleksi, peralatan komputer, sumberdaya manusianya. Komputer dan semua teknologi yang ada merubah semua cara kerja dan kehidupan manusia. Teknologi komputer membantu memperlancar aktivitas yang ada di perpustakaan. Tidak hanya dalam hal perkembangan fisik komputer (hardware) tetapi sofware yang digunakan untuk memudahkan pengguna dan pustakawan dalam menelusur dan mengelola kegiatan di perpustakaan. Hal ini diungkapkan oleh G. Edward Evans dan Sandra M. Helt (1994:19)

We all know that computers and other technologies are changing the way we live and work. Computers also have influence library operations and will continue to do so. Librarians have explored computer applications for library activities since early 1960s. Initially only the large research libraries could afford to seek ways of effectivelly using computers in their day-today activities.

Early applications were aquisitions, cataloging, and circulation. Aquisitions and eireulation application were easy to develop because they were similiar to applications for other business activities; library applications required less revision of standard programs.

Adanya perkembangan sistem jaringan dan otomasi yang ada di UPU Perpustakaan UGM, maka penelusuran dilakukan dengan menggunakan program OPAC. Perkembangan lebih lanjut yaitu pembuatan katalog induk universitas dalam bentuk web site dengan situs alamat http:/www.lib.ugm.ac.id. Katalog induk dibuat bekerjasama dengan bantuan pustakawan di fakultas di lingkungan Universitas Gadjah Mada yaitu dengan selalu meng up-date data entri koleksi perpustakaan di fakultas ke UPU Perpustakaan UGM.

Keberadaan komputer dengan segala kemajuan teknologi komunikasi seakan tidak selalu dikaitkan dengan keberadaan informasi yang dibutuhkan saat itu berada, tetapi bagaimana mengakses in formasi tersebut. Dalam upaya memenuhi kebutuhan pemakai akan informasi tersebut, UPU Perpustakaan UGM berusaha memenuhi melalui sarana teknologi komputer yang disediakan untuk mengakses informas $i$ yang dibutuhkan dengan menggunakan layanan internet.

\section{CARA PENELITIAN}

Cara penelitian menggunakan campuran penelitian deskriptif kualitatif dan penelitian survei. Penggunaan penelitian survei ini dikarenakan jumlah populasi yang cukup besar yaitu pemakai UPU Perpustakaan UGM. Penelitian ini lebih banyak bersifat survei riset, oleh karena itu data-data yang digunakan untuk memberikan analisa atau pembahasan terhadap situasi pemakai teknologi komputer di UPU Perpustakaan UGM. Agar mencapai tingkat pemahaman secara mendalam dari responden diperlukan metode wawancara mendalam (in depth interview). Bahan yang digunakan selain data hasil survei, wawancara, juga data primer dan data sekunder. Informan dikelompokkan sesuai bidang studi yang akan diwawancarai sebagai berikut :

1. Mahasiswa S0 kelompok studi Eksakta 1 orang, dan Non Eksakta 1 orang

2. Mahasiswa S1 kelompok studi Eksakta 1 
orang, dan Non Eksakta 1 orang

3. Mahasiswa S2 kelompok studi Eksakta 1 orang, dan Non Eksakta 1 orang

4. Peneliti/dosen kelompok studi Eksakta 1 orang, dan Non Eksakta l orang

Suharsimi Arikunto (1996: 107) menungkapkan apabila populasi lebih dari 100 dapat diambil 10-20\%, atau 20-25\% atau lebih. Di sini diambil $30 \%$ dari data statistik pengunjung tahun 2004 rata-rata per hari adalah 570 orang (unit I dan Unit I1). Diperoleh jumlah 171 orang, untuk memudahkan dalam perhitungan dibulatkan menjadi 200 orang.

Instrumen yang digunakan berupa daftar pertanyaan kuesioner survei sebanyak 41 butir soal dan wawancara yang mendalam sebanyak 14 butir soal, untuk mengetahui validitas soal-soal diuji dengan Program SPSS versi 11,1 windows XP, analisa deskriptif, nonparametrik. Langkah selanjutnya dengan analisis data berlangsung bersamaan dengan proses pengumpulan data, atau melalui 3 tahapan model alir dari Miles dan Huberman (1992:20) dikutip (Bungin 2003:229) yaitu

1. Tahap reduksi data

2. Penyajian data

Pada tahap ini peneliti melakukan penyajian informasi melalui bentuk teks naratif data lapangan menggunakan tabel data one way.

3. Verifikasi

Pada tahap ini penulis melakukan uji kebenaran setiap makna yang muncul dari data, dengan mengklarifikasi pada informan di lapangan sekiranya masih ada yang kurang, atau untuk memperkuat kesimpulan atas data yang ada.

\section{HASIL PEMBAHASAN}

Kecenderungan pemakai teknologi komputer di UPU Perpustakaan UGM adalah mahasiswa hal ini sangat wajar, karena hampir 98\% pemakainya adalah mahasiswa baik program S0, S1, S2 maupun S3 UGM.

Data Statistik Pengunjung Perpustakaan UGM Dari tahun 2000-2004

\begin{tabular}{|l|l|l|l|l|l|l|l|l|}
\hline No & Keterangan & $\mathbf{2 0 0 0}$ & $\mathbf{2 0 0 1}$ & $\mathbf{2 0 0 2}$ & $\mathbf{2 0 0 3}$ & $\mathbf{2 0 0 4}$ & Jumlah & $\%$ \\
\hline 1. & $\begin{array}{l}\text { Mahasiswa } \\
\text { Eksakta }\end{array}$ & $\mathbf{3 0 . 1 4 6}$ & 31.712 & 32.278 & 34.111 & 35.089 & 163.336 & 35,32 \\
\hline 2. & $\begin{array}{l}\text { Mahasiswa } \\
\text { Non Eksakta }\end{array}$ & 51.541 & 52.591 & 56.912 & 63.045 & 66.045 & 290.134 & 62,75 \\
\hline 3. & $\begin{array}{l}\text { Dosen/ } \\
\text { Asisten }\end{array}$ & 23 & 12 & 41 & 22 & 13 & 111 & 0,02 \\
\hline 4. & $\begin{array}{l}\text { Peneliti/ } \\
\text { Asisten }\end{array}$ & 24 & 29 & 32 & 26 & 45 & 156 & 0,03 \\
\hline 5. & $\begin{array}{l}\text { Staf/ } \\
\text { Karyawan }\end{array}$ & 17 & 34 & 32 & 58 & 56 & 197 & 0,04 \\
\hline 6. & Luar UGM & 1.288 & 1.542 & 1.635 & 1.775 & 2.217 & 8.457 & 1,83 \\
\hline & JUMLAH & 83.039 & 85.920 & 90.930 & 99.037 & 103.465 & 462.391 & 100,00 \\
\hline
\end{tabular}

Sumber Data Primer diolah 2005

Peningkatan jumlah pengunjung selama 5 tahun terakhir, ini menunjukkan trend yang bagus, hal ini seiring dengan perkembangan sarana dan prasarana yang ada di UPU Perpustakaan UGM. Kehadiran pemakai untuk datang ke UPU Perpustakaan UGM atas keinginan sendiri menunjukkan adanya kesadaran membaca yang tinggi pada mahasiswa. Hal ini dapat dipahami karena informasi yang dibutuhkan dapat diperoleh di UPU Perpustakaan UGM. Dari hasil wawancara menunjukkan layanan internet gratis ternyata mampu menarik keinginan pemakai untuk datang ke perpustakaan sampai $90 \%$.

Dari hasil penelitian menunjukkan pengunjung terbanyak berasal dari mahasiswa FISIPOL sebanyak $20,3 \%$, hal ini dikarenakan jumlah mahasiswa FISIPOL merupakan mahasiswa terbesar di Universitas Gadjah Mada, berikutnya Fakultas Ekonomi, dan Fakultas M1PA 9,6\%. Dari segi jarak antara Fakultas ISIPOL dengan UPU Perpustakaan Universitas Gadjah Mada khususnya di gedung Unit I Bulaksumur sangat dekat. demikian pula 
Fakultas Ekonomi dan Fakultas MIPA. Koleksi yang dicari mahasiswa FMIPA kebanyakan koleksi lama. Untuk mencari literatur asli dalam bahasa asing. Sedangkan pengunjung yang paling sedikit jumlahnya dari Fakultas Filsafat, hal ini dikarenakan jumlah mahasiswa Fakultas Filsafat juga sedikit, belum lagi jarak antaranya cukup jauh. Jumlah koleksi yang berhubungan dengan jurusan filsafat juga cenderung minim jumlahnya.

Pengunjung khususnya dari program diploma terbanyak dari D3 MIPA, Teknik, dan FISIPOL hampir sama $16,8 \%, 16,3 \%$ dan $16,1 \%$. Selain itu trend di atas disebabkan koleksi yang ada di perpustakaan jurusan/program studi masih sangat terbatas, dengan jumlah mahasiswa bertambah dari tahun ke tahun. Seperti yang diungkap informan 7 : Ines (D3 Fak. Tenik Jur. Teknik Elektro)

Koleksi Perpustakaan Pusat lumayan lengkap yah, bila dibandingkan dengan yang ada di jurusan, apalagi bidang teknik bisa pinjam koleksi bidang lain baik humaniora maupun bahasa. Di Fakultas dan jurusan tidak ada koleksi bahasa seperti di perpustakaan pusat (belajar bahasa Jepang, Mandarin, Inggris bahkan bahasa daerah di Indonesia

Sedangkan pengunjung yang berstatus mahasiswa Pascasarjana yang datang ke UPU Perpustakaan UGM rata-rata per hari 17 orang, baik di Unit 1 maupun di Unit II.

Ternyata mahasiswa S1 yang datang ke UPU Perpustakaan UGM sebanyak $86,46 \%$, apabila dibandingkan dengan mahasiswa $\mathrm{S} 0$, dan S2 berkisar antara $7 \%-10 \%$. Menurut informasi yang peneliti peroleh dari pemakai mahasiswa S2 (Ahm. Fkh. Pascasarjana) lebih memerlukan informasi untuk bahan pembuatan tugas-tugas penulisan ilmiah (paper). Bahan-bahan yang digunakan biasanya merupakan hasil penelitian yang pernah dilakukan sebelumnya, dan ini hampir $90 \%$ lebih mudah ditemukan di internet. Informasi penelitian di luar negeri jauh lebih maju dari informasi penelitian yang dicari di dalam negeri melalui internet.

Dalam upaya mencari literatur inilah pemakai UPU Perpustakaan Universitas Gadjah Mada lebih suka menggunakan sarana komputer. Hal ini tidak hanya bagi pemakai dari dalam UGM, tetapi juga dari luar UGM sering menggunakan teknologi komputer baik penelusuran dan layanan internet. Namun demikian tidak semua pemakai dari luar UGM mengetahui adanya layanan internet gratis, sedangkan pada kenyataannya pemakai UGM $8 \%$ sering menggunakan komputer untuk penelusuran buku yang akan dipinjam atau difotokopi. Hal ini menunjukkan pemakai dari dalam UGM mengikuti trend perkembangan teknologi.

Pada penelitian ini diperoleh temuan bahwa sebagian besar pemakai yang memanfaatkan teknologi komputer $44 \%$ adalah wanita, dan pria hanya $44 \%$ saja. Hal ini menunjukkan indikasi bahwa wanita lebih telaten mencari informasi yang ada di perpustakaan. Seperti pada penelitian yang dilakukan oleh Astuti, Mary dkk (1997:12) yang melakukan penelitian bahwa dijumpai sarjana wanita yang lebih banyak jumlahnya dibandingkan sarjana pria. B e r d a s a r k a n jenjang angkatan pemakai potensial yang datang ke UPU Perpustakaan UGM, ditemukan rata-rata mahasiswa angkatan antara 1999 sampai dengan 2004. Dilihat dari masa studi mahasiswa S1 Universitas Gadjah Mada berkisar antara 4 sampai 4,5 tahun, S0 antara 2 sampai dengan 3 tahun dan S2 berkisar antara 2 sampai 3 tahun. Dari data di atas mahasiswa angkatan 2001 paling banyak yaitu $42 \%$ dari 6 jenjang studi angkatan. Mahasiswa angkatan tahun 2001 apabila dihitung sampai dengan tahun 2005 merupakan 4 tahun masa studi, biasanya pada tahun ke 4 itulah tepat semester 8 , di mana mahasiswa Sl mulai melakukan penulisan skripsi atau penelitian untuk skripsi. Dalam penelitian ini peneliti membaginya menjadi 6 kelompok yaitu karyawan (petugas perpustakaan, pustakawan) $3 \%$, dosen $3 \%$, sarjana $72 \%$, diploma $17 \%$, program magister $5 \%$, program doktor $0 \%$ dan peneliti juga $0 \%$. Pemakai potensial di UPU Perpustakaan UGM adalah mahasiswa S1 angkatan 2001 sebesar $72 \%$. Pemakai dari luar UGM cenderung merujuk bahan-bahan referensi di UGM untuk mendukung penelitiannya. 
Menurut mereka, hanya sebagian hasil-hasil seminar dan penelitian yang ada di UPU Perpustakaan UGM dapat diakses melalui internet, dan di browsing melalui tempat asal mereka.

Karakteristik pemakai berdasarkan asal pemakai yaitu dari Daerah Istimewa Yogyakarta sebanyak 27\% dan dari Luar Daerah Istimewa Yogyakarta sebanyak $73 \%$. Hasil penelitian ini menunjukkan minat ke perpustakaan UGM cenderung paling banyak pemakai dari luar DIY. Karakteristik lain berdasarkan status perkawinan dalam penelitian ini mahasiswa $\mathrm{S} 1$ bersatus belum menikah yaitu $93 \%$ dan status yang sudah menikah pemakai yang berstatus dosen, mahasiswa S2 dan karyawan (termasuk pustakawan).

Pemakai sering mempergunakan teknologi komputer untuk penelusuran buku untuk dipinjam ataupun difotokopi. Mereka mempergunakan sarana ini $58 \%$ untuk menelusur yaitu mencari informasi tentang koleksi yang ada di UPU Perpustakaan UGM dan memanfaatkan layanan internet. Dari hasil wawancara, ternyata selain digunakan untuk penelusuran (retrieval) katalog buku-buku yang akan dipinjam, juga untuk menelusur informasi di internet. Dari hasil di atas ternyata pemakai UPU Perpustakaan UGM selalu mengikuti era teknologi.

Penggunaan komputer dalam kondisi antri untuk penelusuran buku yang hendak dipinjam, nampak bahwasanya ada juga pemakai yang kurang sabar ketika proses menelusur. Cross cek dengan informan (NNK Fak MIPA)

"daripada nunggu antrian lebih baik datang pagi-pagi atau menjelang maghrib, wah pasti agak sepi, malaslah kalau waktu habis untuk antri internet...."

Sedangkan dari hasil survei nampak bahwa responden yang menjawab antri $15 \%$, tidak antri $51 \%$ dan kadang-kadang antri 34\%. Pemanfaatan teknologi komputer tersebut ternyata fasilitas yang disediakan telah mencukupi dalam arti pada jam-jam tertentu terjadi antrian dan kadangkadang tidak terjadi antrian sebesar $68 \%$. Pada jam-jam antara 07.30 sampai dengan 09.00 unit komputer untuk penelusuran katalog dan internet terlihat santai (tidak ada antrian). Setelah pukul 09.00 sampai dengan 15.00 merupakan jam sibuk, sering terjadi antrian, namun demikian dengan peraturan per 30 menit akses internet, tidak menimbulkan antrian yang panjang. Di sisi lain pemakai merasa terlalu pendek jam akses internetnya, karena pada jam-jam sibuk proses download di internet terasa lambat. Berikut ini beberapa saran dari pemakai sehubungan dengan sering antri dan tidaknya pemakai ketika hendak menggunakan komputer untuk penelusuran katalog:

\section{Penggunaan komputer dibatasi}

2. Agar dapat browsing internet secara gratis

3. Diharapkan layanan internet sampai pukul 20.00, pada waktu itu perpustakaan bakal ramai dan layanan perlu ditingkatkan lagi

4. Perlu tambah komputer saran diberi tempat duduk

5. Penggunaan komputer ditambah

Pemakai sering mencari informasi yang berhubungan dengan hasil temuan teknologi tinggi baik yang ada di dalam maupun di luar negeri. Dari hasil wawancara pemakai pada saat observasi dan cross cek, pemakai dari Fakultas ISIPOL UGM ternyata sangat suka di layanan internet guna menjelajah di internet, mengapa demikian, menurut responden (alasan dalam kuesioner survei) (Lkm, mahasiswa FISIPOL UGM)

"sarana ini untuk mendapatkan informasi perkembangan gejolak politik, baik di dalam maupun di luar, kita tidak perlu membeli surat kabar atau punya TV kabel (bagi kita yang kost), perlu biaya, dan tidak semua surat kabar dapat memberikan informasi yang cepat, tepat dan akurat sesuai dengan yang diinginkan. Melalui internet bila kita menginginkan informasinya dan bisa langsung didownload. "

Sedangkan mahasiswa Dy WP Fakultas Pertanian 03 mengungkapkan:

"Bagi saya melalui internet bisa memperoleh 
informasi dan berita terbaru baik di dalam maupun di luar negeri dapat dengan cepat dan hemat waktu"

Pemanfaatan teknologi komputer terutama pada saat mengakses (kecepatan akses) internet menjadi salah satu pertimbangan. Hal ini dapat dilihat pada presentase kecepatan mengakses internet responden menjawab akses internetnya cepat $24 \%$, lumayan/sedang $67 \%$ dan lambat $9 \%$.

Seperti pendapat informan 1 Ags S1 Fak Pertanian mengungkapkan:

"Hanya sayangnya jumlah unit komputer yang tersedia hanya terbatas (4 buah di Ruang Sirkulasi), itupun harus berbagi dengan mahasiswa lain dengan jangka waktu yang terlalu cepat, .........mengapa demikian, .... Karena kalau aksesnya tidak cepat, waktunya habis untuk browsing atau download suatu artikel. Sedangkan untuk download suatu artikel atau temuan memerlukan waktu yang cukup lama di saat jam sibuk."

\section{Informan Bdn mahasiswa D3 Ekonomi :}

"Akses internetnya cukup bagus aksesnya, tapi kalau bisa ditambah unit komputernya, tapi jangan dibagi jaringannya. Jadi aksesnya tetap cepat"

Nampak dari hasil wawancara bahwa $80 \%$ pemakai menginginkan akses internet cepat, walaupun kenyataan pemakai mengganggap kecepatan aksesnya cukup lumayan.

Tidak hanya dari segi kecepatan aksesnya pemakai melihat dari segi kemudahan dalam mengoperasikan software yang digunakan untuk penelusuran katalog, nampak bahwa pemakai tidak merasa kesulitan ketika mengoperasikan. Alasan yang diberikan oleh salah satu responden (Lkm/Jur.Agro) bahwa program softwarenya sudah bagus karena menggunakan bahasa Indonesia sehingga mudah dipahami. Saran pemakai tentang kenyamanan pemakaian komputer untuk layanan diharapkan perlu disediakan kursi di layanan internet (kecuali di Ruang American Corner). Hasil observasi menunjukkan memang tidak disediakan kursi (posisi pemakai berdiri), hal ini jelas sangat tidak nyaman, seperti terungkap oleh salah satu responden (Ayu mHS FIB), dalam saran pemakai:

"tolong diberi kursi, layanan internetnya, ..

.. kursi untuk internet manaa..:

wah tidak nyaman nih....

..tidak diberi kursi pegel buu....dst...”.

Tidak disediakannya kursi di cross dengan Kabid TI (Bapak Wahyu, 18 Oktober 2005) memang disengaja karena supaya pemakai tidak nyaman karena jumlah unit komputer sedikit, sedangkan pemakai jauh lebih banyak, dan agar antrian tidak terlalu lama. Pemakaian software SIPUS bagi pemakai tidak menjadi masalah karena begitu mudah dipahami, dan tidak berbelit-belit. Hal ini diungkapkan oleh pemakai berdasarkan informan HZT/F. Ilmu Budaya2001:

"perintah dalam software program SIPUS sangatlah mudah, selain menggunakan bahasa Indonesia, perintah dan tampilannya sangat menarik, simple dan mudah dipahami."

\section{Berdasarkan informan Ines FT:}

"Masalah program SIPUS ISIS dan Katalog Online atau lain-lain menurut saya biasa tapi sederhana dan mudah dipahami ini sangat membantu kalau kita hendak mencari buku/koleksi yang akan dipinjam"

Program ini perlu disosialisasikan/ dikenalkan terlebih dahulu, karena program SIPUS ini merupakan olah teknologi yang dikerjakan bersama antara tim pustakawan sebagai yang akan mengoperasikan dan tim teknologi informasi yang menguasai dari bidang softwarenya. Sehingga hasil yang ditampilkan memudah pustakawan pada saat memberikan layanan dan penjelasan ke pemakai. Pemakai sendiri tidak merasa kesulitan pada saat pengoperasiannya. Pemakai merasa mudah ketika menggunakan program SIPUS $51 \%$, kadang-kadang mudah $27 \%$ dan tidak mudah $22 \%$. Alasannya adalah cara yang lebih praktis dengan 1,2 klik saja. Selain itu program sofware SIPUS fleksibel dalam penggunaannya.

Apabila terjadi kesalahan atau kesulitan 
dalain mengoperasikan program-program perpustakaan yang ada di komputer, $65 \%$ pemakai cenderung bertanya ke petugas. Sedangkan yang memberi jawaban diam saja $12 \%$, pura-pura tidak tahu $4 \%$, mencoba meinbetulkan sendiri 16\% dan lainnya 3\%. Hal ini dapat diartikan sebagai adanya hubungan interaksi antara pemakai dengan staf/pustakawan. Namun interaksi ini tidak hanya terjadi pada saat akan menggunakan, tetapi bisa juga interaksi setelah buku itu diketemukan kode letak buku itu berada, dan pemakai tinggal mencari di mana posisi rak tempat buku tersebut berada. Setelah dikonfirmasikan dengan hasil wawancara dari informan, (NNK/FMIPA S22002) pemakai merasa petugas/pustakawan jauh lebih tahu program yang ada di perpustakaan, sehingga bertanya langsung ke petugas.

Pembagian unit komputer di ruang layanan cukup merata antara $15-22 \%$ dan pemakai menganggap setiap unit layanan sudah tercukupi.

Keluhan yang dilontarkan pemakai dalam hal ini salah satu responden (Dew/F.Pertanian) mengapa waktu yang disediakan untuk mengakses internet sangat pendek hanya 30 menit. Dari cros cek dengan responden yang mengusulkan akses internet per 3 jam $(65$ responden). Sedangkan untuk browsing dan download hasil temu kembali informasi meinerlukan waktu yang tidak cepat, uji coba peneliti lakukan untuk browsing hasil temuan internet memerlukan waktu kurang lebih 15-20 menit pada jam-jam sibuk dengan hasil tanpa gambar/grafik, karena dengan gambar/grafik diperlukan tambahan waktu kecepatan aksesnya. Sedangkan fasilitas jaringan Wi Fi yang disiapkan oleh UPU Perpustakaan UGM untuk melayani pemakai yang memiliki sarana note book (lap top) agar dapat diakses di UPU Perpustakaan UGM, mendapat tanggapan pemakai melalui kuesioner survei $78 \%$ yang menyatakan fasilitas ini bagus, dapat menghemat dana, tenaga dan waktu.

Pemakaian layanan internet gratis menjadi suatu harapan yang cukup besar bagi pemakai, karena hal ini terungkap dalam wawancara mendalam. Hampir $80 \%$ responden dan $75 \%$ inforınan mengatakan keberadaan dan keputusan UPU Perpustakaan UGM untuk memberikan layanan internet gratis menjadi salah satu motivasi yang besar bagi pemakai untuk datang ke UPU Perpustakaan UGM. Sedangkan layanan nirkabel Wi Fi yang diberikan sebagai salah satu sarana layanan gratis khususnya pemakai yang menggunakan lap top akan memberikan dampak kemudahan untuk melakukan tugas-tugas di perpustakaan, dengan harapan perpustakaan dapat menjadi rumah kedua. Selain itu akan menghemat biaya jaringan dan listrik. Pendapat responden tentang bagus, tidaknya dengan adanya fasilitas jaringan nirkabel pada penelitian ini $6 \%$ menyatakan bagus dan $78 \%$ menyatakan biasa, sedangkan $10 \%$ menjawab tidak bagus.

Sedangkan proses layanan sirkulasi di perpustakaan meliputi proses peminjaman buku dan pengembalian buku. Dalam proses ini pasti terjadi juga pelanggaran peraturan tata tertib peminjaman buku dan terjadi keterlambatan pengembalian buku ini menimbulkan denda. Sebanyak $74 \%$ mahasiswa merasakan penggunaan komputer untuk perhitungan denda, sudah sesuai dengan harapan mereka. Sedangkan $15 \%$ pemakai yang tidak tahu setelah di cros cek ternyata pemakai ini jarang atau tidak pernah terlambat mengembalikan buku pinjaman. Maka wajar saja apabila pemakai ini tidak tahu perihal perhitungan denda. Sedangkan $11 \%$ mengatakan tidak sesuai penyebabnya adalah kondisi sitem denda disetting berjalan terus sesuai dengan waktu, walaupun hari Minggu atau libur nasional, ataupun dapat di set untuk dihapus (ini sering terjadi apabila terjadi listrik mati). Ini dilakukan oleh petugas dengan beberapa pertimbangan setelah hasil cros cek dengan petugas/ pustakawan di ruang sirkulasi dan cadangan, dalam arti setelah dicross cek kondisi buku pinjaman sudah kembali, terus sedangkan data peminjam masih tercantum dan proses denda berlangsung.

Namun menurut 10 responden memberikan alasan denda yang diterapkan menggunakan teknologi komputer untuk membantu perhitungan biasanya jauh lebih akurat.

Dari sisi petugas program ini sangat 
membantu karena tidak perlu menghitung sudah otomatis akan muncul setiap pemakai yang terlambat mengembalikan buku. Namun ada sisi yang lain dari segi pemakai ada yang kurang menguntungkan. Mengapa demikian artinya terjadi kesalahan seting program seperti diungkap di muka, menimbulkan kesalahpahaman antara pemakai dan petugas, artinya masih ada kekurangan dari sistem yang digunakan.

Penelusuran informasi dilakukan untuk mencari koleksi buku yang dimiliki perpustakaan di lingkungan UGM dapat dilakukan di luar gedung UPU Perpustakaan UGM (pengunjung/pemakai maya, tidak diteliti dalam penelitian ini). UPU Perpustakaan UGM melanggan database EBSCO yang berisi daftar jurnal, hasil penelitian baik dalam bentuk fulltext ataupun abstraknya. Namun berdasarkan hasil penelitian nampak hampir $58 \%$ pemakai tidak mengetahui adanya we bite http:/www.lib.ugm.ac.id. dan $42 \%$ menjawab mengetahui.Bagi pemakai yang mengetahui website ini, biasanya pemakai ini sering datang ke UPU Perpustakaan UGM. Sedangkan Presentase pendapat responden tentang tampilan website lib.ugm.ac.id, $21 \%$ menyatakan bagus, $35 \%$ menyatakan biasa, $22 \%$ menyatakan lumayan, $13 \%$ meyatakan tidak menarik dan lainnya $9 \%$.

Namun demikian pemakai yang memberikan alasan lainnya sebanyak 9\% diantaranya:

"Warnet

Situs Ugm ac id kurang lengkap

Lumayan juga

Wah ada peningkatan Perpustakaan UGM"

Hal ini sejalan dengan pendapat dari salah satu informan dari pemakai mahasiswa S2 (US/S2 Sosiologi), ternyata:

"saya sering menjelajah ke internet, tidak hanya di rumah, di warnet untuk mencari bahan-bahan pendukung penulisan tugastugas dosen. Karena bahan yang dirujuk oleh dosen tidak selalu tersedia di perpustakaan pusat, pascasarjana dan jurusan"
Pemakai mengetahui website UPU Perpustakaan UGM dari warnet di UPU Perpustakaan UGM Unit II sebanyak 7 responden, surat kabar KABAR UGM (5 orang), leaflet (3 orang), website UGM (2 orang). Pemakai mengetahui keberadaan website UPU Perpustakaan UGM dari teman kuliah sebesar $32,69 \%$, dosen/pengajar $4,8 \%$, saudara $25 \%$, leaflet/brosur $29,8 \%$ dan lainnya $7,69 \%$. Ini menunjukkan adanya interaksi sosial yang cukup tinggi, di mana informasi yang dimiliki seseorang dan mempunyai nilai lebih akan disampaikan ke orang lain. Sedangkan yang pernah membuka website http:/www.lib.ugm.ac.id ada $42 \%$ saja. Ternyata setelah dicros cek dengan hasil wawancara mendalam ke informan (HZT/F.Ilmu Budaya-2001 dan NNk/FM1PA/S2-2002), diketahui bahwasa

"informasi ini kurang sosialisasi. Jadi hanya beberapa mahasiswa yang memang sering berkunjung ke UPU Perpustakaan UGM yang tahu akan fasilitas yang baru disediakan untuk pemakai. Informasi perkembangan UPU Perpustakaan UGM kurang sosialisasi ke fakultas-fakultas di lingkungan UGM."

Pendapat pemakai tentang situs lib.ugm.ac.id ternyata bermacam-macam diantaranya:

1. Situs lib.ugm.ac.id kurang lengkap informasinya

2. Informasi tidak menyeluruh tentang perpustakaan yang ada di lingkungan UGM

3. Perlu ditambah daftar situs ilmiah, pengetahuan umum dan berita

4. Luar biasa perpustakaan UGM semakin oke

5. Bagus juga

6. Lumayan

7. Biasa

8. User friendly

Dari hasil wawancara ditemukan informasi yang dibutuhkan pemakai (Bdn/F.Ekonomi D3-2003)menyatakan bahwa pada saat ini tidak semua pemakai mencoba database ini. Karena content (isi) database dari perpustakaan fakultas di lingkungan UGM baru 
saja mulai ditampilkan di dalam situs tersebut. Dengan demikian wajar kalau pada saat peneliti menyebarkan kuesioner ini hanya sebagian responden yang telah mengetahui yang menjawab pernah menggunakan fasilitas ini.

1) Ketersediaan koleksi dalam bentuk fisik untuk memenuhi kebutuhan pemakai, belum semua terpenuhi secara sama dan merata. Ketersediaan koleksi yang ada rata-rata berkisar di atas $60 \%$ yang sesuai dengan kebutuhan, walaupun dari kuesioner ada 4 responden yang menjawab koleksi UPU Perpustakaan UGM cukup lengkap dibandingkan di fakultas atau jurusannya. Berikut persentase pemakai tentang ketersediaan koleksi yang sesuai dengan kebutuhan pemakai di UPU Perpustakaan UGM $100 \%$ sesuai dengan studi saya (referensi yang ditunjuk dosen) $2 \%, 75 \%$ responden menjawab $44 \%, 50 \%$ responden menjawab $27 \%, 25 \%$ responden menjawab $14 \%, 10 \%$ responden menjawab $7 \%$, sama sekali tidak ada yang relevan dengan program studi saya $4 \%$ dan lainnya ada $2 \%$. Namun demikian terjadi kontradiksi dengan 8 responden yang mengatakan sama sekali tidak relevan yaitu responden Anj/F. S2: Studi transportasi, menurutnya minim buku-buku tentang transportasi, hampir kebanyakan hasil penelitian atau ada di jurnal-jurnal asing. Responden Oct/F. Filsafat, juga mengungkap pertambahan koleksi bidang ilmu filsafat juga sangat sedikit perkembangannya, hasil cros cek dengan bagian pengadaan UPU Perpustakaan UGM, memang untuk bidang ilmu Filsafat jatah pengadaan buku jarang dan sedikit, akan tetapi apabila ada permintaan pengadaan buku bidang tersebut tetap akan menjadi prioritas walaupun tidak sebanyak bidang lain seperti ilmu-ilmu komputer, teknik, pertanian dan industri.

Apabila dilihat berdasarkan presentase ketersediaan kebutuhan koleksi $34 \%$ memenuhi, dan $66 \%$ tidak memenuhi. Ada beberapa koleksi bidang ilmu tertentu yang belum memenuhi kebutuhan pemakai, koleksi UPU Perpustakaan UGM (2003) terdiri dari semua bidang ilmu tidak hanya pada salah satu bidang ilmu saja, tetapi ada 18 fakultas dan satu sekolah pascasarjana. Pemenuhan kebutuhan akan koleksi terus ditingkatkan dalam arti dengan banyaknya program studi di lingkungan UGM, dana yang tersedia tidak memadai untuk memenuhi kebutuhan buku-buku di semua program studi. Dengan adanya perpustakaan di fakultas, jurusan, pusat antar universitas, bahkan di pusat studi akan membantu melengkapi ragam koleksi yang ada di UPU Perpustakaan UGM. Namun demikian UPU Perpustakaan UGM selalu menyediakan blangko isian usulan pengadaan buku yang diwajibkan pemakai dari fakultas masing-masing, di mana perpustakaan fakultas tidak memiliki koleksinya. Dengan demikian antara perpustakaan fakultas, jurusan, pusat studi di lingkungan UGM akan saling melengkapi satu dengan yang lain.

Apabila koleksi yang dicari dalam bentuk fisik (buku, CD, kaset, jurnal, paper, hasil penelitian, surat kabar, majalah dan lainnya) yang dicari tidak ada, dapat ditempuh dengan cara lain yaitu pemanfaatkan komputer untuk browsing ke internet. Seperti pernah diungkap dalam reportasi Uminurida S. dan Lilik K. Uswah (2000:41) pada Media Informasi

"Internet merupakan sarana yang sangat membantu dalam mendapatkan informasi ilmiah. Hal ini dirasakan oleh mahasiswa, baik strata 1, tingkat magister maupun program doktor dan para dosen. Mahasiswa S-2 yang sering memanfaatkan internet di UPT Perpustakaan UGM Unit II Sekip yang tidak mau disebut jati dirinya, kalau sedang bingung mencari literatur untuk mendukung makalahnya akan lari ke dunia maya (internet)".

Pemakai dari jauh (pemakai maya) juga cukup banyak, bahkan seluruh nusantara, mengapa demikian, karena pada web site lib.ugm. sudah ditampilkan portal database katalog induk, database on line dan lain-lain. Dari sini pemakai dari luar UGM bisa mengakses informasi yang dibutuhkan sehubungan dengan penelusuran literatur. Berikut ini pemakai riil layanan internet baik di Unit I dan Unit II : 
Statistik pemakai riil layanan internet di UPU Perpustakaan UGM

\begin{tabular}{|l|l|r|r|r|r|}
\hline \multirow{2}{*}{$\begin{array}{c}\text { No } \\
\text { Layanan }\end{array}$} & \multicolumn{2}{|c|}{ Tahun 2004 } & \multicolumn{2}{c|}{ Tahun 2005 } \\
\cline { 2 - 6 } & November & Desenber & Januari & Februari \\
\hline 1. & Sirkulasi & 3967 & 7774 & 5443 & 6026 \\
\hline 2. & $\begin{array}{l}\text { Spot } \\
\text { Control } \\
\text { (Unit J) }\end{array}$ & 1221 & 2008 & 1900 & 2898 \\
\hline
\end{tabular}

Sumber Data Primer diolah tahun 2005

Kehadiran layanan internet ikut andil meningkatkan jumlah pemakai dalam hal ini jumlah pengunjung. Pada tabel di atas terlihat pada bulan November 2004 jumlah pengunjung di Sirkulasi 3967 orang, dan terjadi peningkatan pada bulan Desember 2004 ini dikarenakan pada bulan-bulan Agustus dan Desember adalah bulan jadwal ujian semesteran mahasiswa. Jadi pengunjung lebih banyak dari biasanya. Pada bulan Januari dan Februari 2005 terjadi peningkatan seperti di Spot Control dan Sirkulasi. Data yang diperoleh penulis, menunjukkan statistik pengunjung perhari mencapai sekitar 40 an pengunjung.

Berdasarkan respon di atas nampak $87 \%$ pemakai yang memanfaatkan komputer untuk penelusuran. Internet dapat membantu pencarian pustaka/informasi. Ketersediaan jaringan internet benar-benar membantu pemakai untuk memenuhi kebutuhan akan informasi. Hal inilah yang sudah ditanggapi oleh UPU Perpustakaan UGM, walaupun dengan sarana yang bagi pemakai masih perlu ditambah kuantitasnya, namun telah cukup membantu memenuhi sebagian kebutuhan pemakainya. Limb, Peter (2004:96) mengungkapkan bahwa:

The digital revolution has spawned many changes to public and educational practices and provided powerful new tools to access information. It is important to know how effectively patrons understand and operate these tools and how libraries can better help them to exploit the new technology.

Presentase pemanfaatan jaringan internet oleh pemakai pada penelitian ini ditemukan $30 \%$ responden yang membuka e-mail dan kirim email, $63 \%$ download, mencari informasi, $6 \%$ menggunakan chatting dan lainnya menjawab $1 \%$.Sedangkan lainnya memilih men-download surat kabar asing, jurnal asing, jurnal online yang dilanggan dan informasi terbaru ilmu kedokteran (belum termasuk pemakai maya). Ini membuktikan bahwa jaringan internet, sarana komputer dan teknologinya dapat memenuhi kebutuhan informasi baik di dalam maupun di luar negeri.

Ternyata pemakai UPU Perpustakaan UGM mengetahui adanya sarana dan teknologi komputer $40 \%$ berasal dari teman kuliah, $4 \%$ dari dosen/pengajar, 26\% dari saudara, dan leaflet $30 \%$. Ida Fajar Priyanto (2002) yang mengatakan survei menunjukkan bahwa layanan yang prima yang diberikan menimbulkan dampak, diantaranya pemakai tidak akan datang lagi dikarenakan $68 \%$ kecewa dalam treatment, 14\% tidak puas dengan layanan/produk, 5\% mencari alternatif baru. Namun apabila pemakai yang puas dengan layanan yang diberikan akan bercerita pada 3 orang lain. Sedangkan pemakai yang tidak puas akan bercerita pada kurang lebih 10 orang lain. Berdasarkan leaflet atau brosur yang disediakan sebanyak $30 \%$. Hal ini juga berkaitan dengan adanya teori interaksi sosial yang diungkap pada Moh. As,ad dkk (1990 : 24) sebagai makluk sosial, manusia selalu mengadakan interaksi sosial dalam segala aktivitasnya.

Hasil wawancara dengan salah satu pemakai, (Ach/F.Pertanian) mengatakan bahwa koleksi UPU Perpustakaan UGM cukup lumayan, karena cukup banyak buku-buku baru yang mereka butuhkan, namun kebanyakan buku baru ini banyak peminatnya, sehingga frekuensi pemakaiannya cukup banyak. Hal ini menimbulkan dampak pada fisik buku menjadi jelek, kumal, kotor, bahkan rusakjilidannya.

Informasi keberadaan koleksi/pustaka yang dibutuhkan 51\% disampaikan melalui teman, $13 \%$ melalui leaflet, dosen $26 \%$, saudara $0 \%$ dan lainnya $10 \%$. Ini menunjukkan bahwa peranan interaksi lingkungan sosial sekitar sangat berpengaruh. Teman sangat berpengaruh besar untuk ikut andil dalam memberikan informasi keberadaan koleksi baru di UPU Perpustakaan 
UGM. Dari hasil cross cek wawancara dengan informan, hampir $90 \%$ informan menyampaikan bahwa pengetahuan tentang keberadaan koleksi yang akan dicari berasal dari teman. Kebiasaan saling berbagi informasi yang dikomunikasikan dengan teman merupakan bagian dari manusia sebagai makhluk sosial.

Interaksi sosial antara staf/pustakawan dengan staf/pustakawan dapat dilakukan setiap waktu dalam arti kedua-duanya ada keinginan untuk berkomunikasi. Apabila pemakai sedang melakukan penelusuran baik yang menggunakan katalog komputer, penelusuran internet, maupun kegiatan yang ada hubungannya dengan layanan perpustakaan, mengalami kesulitan akan bertanya ke petugas. Demikian juga pada saat pemakai bertanya pada salah satu staf ketika komputer yang dipergunakan pemakai dalam posisi 'trouble/tidak bereaksi', maka akan dimintakan bantuan ke staf Tl (Teknologi Informasi) yang lain yang sekiranya mampu membantu. Apabila terjadi kesalahan pemanfaatan teknologi komputer, maka pemakai akan berkecenderungan bertanya ke petugas. Nampak $65 \%$ pemakai akan bertanya ke petugas apabila terjadi kesalahan/kesulitan pada saat memanfaatkan teknologi komputer. Hal ini karena menurut pemakai, petugas akan jauh lebih tahu akan program-program yang ada di perpustakaan.

Pemakai menghendaki kenyamanan, kecepatan, ketepatan, kemudahan, bahkan menghemat dana agar mendapatkan fasilitas yang disediakan UPU Perpustakaan UGM. Baik bentuk fisik (gedung, furnitur, unit komputer, koleksi, ruangan, $\mathrm{AC}$, penerangan dan kamar mandi) maupun non fisik (sumberdaya manusia). Beberapa hasil evaluasi dari monitoring dan harapan mahasiswa berdasarkan kuesioner survei dan wawancara, pertama UPU Perpustakaan UGM telah menyediakan ruangan ber-AC di ruang Sirkulasi dan Cadangan, penerangan lampu di ruang tersebut juga sudah dibenahi. Kedua dengan adanya kebijakan baru untuk memudahkan dan memberikan rasa adil bagi semua anggota UPU Perpustakaan UGM yaitu penggunaan KARTU PINJAM bagi semua anggota termasuk staf dan pustakawan yang juga ingin meminjam buku. Sehingga proses layanan sirkulasi dan cadangan dapat berjalan dengan lancar tanpa dua peraturan yang membedakan satu dengan yang lain.

Dari hasil penelitian ini ada beberapa masukan dari pemakai, ternyata ada juga pemakai yang merasa tidak nyaman dengan sikap petugas/pustakawan. Responden memberikan pendapat sebanyak $52 \%$ menjawab bahwa sikap petugas/pustakawan ketika memberikan layanan sesuai dengan harapan. Hal ini menunjukkan bahwa petugas/pustakawan sudah memberikan sikap sesuai dengan harapan pemakai. Apa harapan pemakai tersebut, diungkap beberapa responden diantaranya:

1. Petugas/pustakawan mau membantu memberikan informasi yang dibutulıkan baik letak buku yang dicari,

2. cara mencari di katalog SIPUS

3. cara memesan buku yang diinginkan untuk dipinjam

4. memberikan layanan dengan ramah

5. membantu menelusur buku yang diinginkan melalui katalog komputer

6. membantu ke rak-rak mencari buku

Sedangkan dilihat dari mahasiswa yang merasa tidak sesuai dengan harapan sampai dengan $48 \%$, setelah dicros cek ternyata beberapa buku yang ditemukan dalam katalog komputer tidak ditemukan di rak, setelah di tanya ke petugas, petugasnya kebingungan menjawab. Seperti contoh ada satu judul buku dengan jumlah jeksemplarnya 5 yang dipinjam 3 buku, dan 2 buku yang lain kok tidak ada. Namun demikian ada juga petugas yang mau memberikan jawaban lain bahwasanya buku yang diinginkannya hilang, rusak (dalam parawatan) atau pindah posisi raknya.

Jam layanan yang diberikan ke pemakai sampai saat ini mengalami perubahan, ternyata pemakai menghendaki jam layanan terutama untuk layanan internet mendapat tanggapan $70 \%$ pemakai merasa sudah cukup, dalam arti layanan 6 hari setiap minggu dan per hari mulai pukul 08.00 s.d. 16.00 , bahkan unit II layanan sikulasi 
dari pagi sampai dengan pukul 20.00. malam. Tanggapan pemakai perlunya penambahan jam layanan internet bagi pemakai $70 \%$ menjawab sudah mencukupi dan $30 \%$ belum mencukupi. Sedangkan alasan bagi mereka yang menjawab belum cukup terangkum sebagai berikut:

"Jam layanan sampai jam 6 sore

Layanan sampai jam 6 sore

Buka sampai dengan jam 9 malam

layanan hari Sabtu sampai jam 20.00

layanan UPT $24 \mathrm{jam}$ biar tenang fleksibel dan buat baca-baca

Jam layanan dari jam 7 pagi sampai jam 9 malam"

Ini semua menunjukkan keinginan pemakai agar dapat memanfaatkan fasilitas yang ada di UPU Perpustakaan UGM sebaik-baiknya, seperti halnya sebagai rumah kedua. Teknologi komputer yang otomatis berhubungan dengan pemanfaatkan listrik, sewa jaringan dan perangkat komputer menurut pemakai mampu menghemat dana.

UPU Perpustakaan UGM ternyata memiliki keunggulan dan kelebihan di bandingkan dengan perpustakaan fakultas dan jurusan. Mengapa demikian, hal ini terungkap dari hasil kuesioner survei yang memilih koleksi dan sarana komputer menjadi salah satu unggulan antara $35-36 \%$ Namun demikian tidak menutup kemungkinan pada saat yang sama koleksi juga menjadi kelemahan bagi UPU Perpustakaan UGM dibandingkan dengan perpustakaan fakultas dan jurusan. Hal ini dapat dimaklumi, karena responden yang mengisi kuesioner membandingkan kelengkapan dari segi spesifikasi koleksi buku yang ada di fakultas atau jurusan jauh lebih lengkap. Karena di fakultas/jurusan pengadaan buku cenderung lebih ke bidang subyek yang lebih spesifik. Tanggapan pemakai perihal keunggulan/ kelebihan yang dimiliki UPU Perpustakaan UGM di bandingkan dengan perpustakaan di fakultas dan jurusan yaitu koleksinya $35 \%$, bangunnya $12 \%$, sarana komputernya $36 \%$, tidak tahu $7 \%$ dan lainnya $10 \%$. Sedangkan responden (Aly, FISIPOL 2003 dan Eka Fpertanian 2004) yang memilih jawaban lainnya memberikan usulan sebagai berikut:

1. Ruangannya kurang harum

2. Perpustakaan UGM unggul dibidang koleksinya (banyak buku baru)

3. Koleksi lebih lengkap

4. Koleksi cukuplengkap

5. Fakultas Hukum tidak ada komputer, Tidak berAC koleksi UPT lebih variatif

6. Fakultas lebih lengkap dan di UPT perpustakaan suasana bising

7. Internetnya dan buka sampai malam, ini kelebihannya

8. Di Fak tidak ada internetnya koleksi lebih variatif, bangunan lebih besar

9. Koleksinya multi disiplin, bangunan lebih luas, komputer lebih banyak

10. Unggul UPT karena internet gratis

11. Koleksi sirkulasi sedikit

12. UPT Konnut aksesnya cepat, di fak koleksi kurang lengkap

13. Tata buku berantakan, perlu tambahan $\mathrm{AC}$

14. Manfaat internet lebih mudah (cepat)

15. Internet gratis hemat

\section{KESIMPULAN}

Teknologi komputer sangat berpengaruh pada perkembangan informasi dan ilmu pengetahuan. Hal ini berdampak pada pencari informasi. Tolok ukur suatu keberhasilan sebuah pelayanan adalah kepuasan pemakainya, karena pemakai merasakan adanya kenyamanan dan pemenuhan kebutuhan informasi secara cepat, tepat, akurat, dan murah. Teknologi komputer mampu mempercepat temu kembali informasi yang dibutuhkan. UPU Perpustakaan UGM menambahkan beberapa unit komputer baru dan membuka layanan internet gratis $\mathrm{Hal}$ ini memberikan dampak positif, artinya pemakai menjadi termotivasi untuk datang ke perpustakaan. Sekalipun informasi yang dibutuhkan berada di luar negeri pemakai dapat 
memperolehnya dengan cepat, tepat dan akurat melalui layanan internet.

Faktor-faktor yang mempengaruhi pemanfaatan teknologi komputer tersebut di antaranya faktor lingkungan sosial, kondisi hardware dan software. Faktor lingkungan dapat meliputi 2 hal antara lain pemakai (user), dan pengelola (tim manajemen dengan staf dan pustakawannya). Pemakai (user) berpengaruh dalam memberikan informasi adanya fasilitas teknologi, buku-buku, dan sarana lainnya yang dibutuhkan kepada pemakai yang lain. Faktor lingkungan di sini dengan maksud hubungan antara pemakai dengan pemakai terjadi interaksi yang positif. Artinya informasi yang pemakai peroleh akan disebarkan ke pemakai yang lain dengan cepat. Demikian juga interaksi pemakai dengan petugas/pustakawan akan terjalin dengan baik apabila informasi yang dibutuhkan pemakai dapat dipenuhi oleh petugas/pustakawan. Kondisi jaringan internet, kecepatan akses dan jumlah unit komputernya mempengaruhi kesediaan pemakai untuk memanfaatkan fasilitas yang ada untuk memenuhi kebutuhan informasinya. Ada juga faktor lain sehubungan dengan kenyamanan pemakai ketika memanfaatkan fasilitas perpustakaan, diantaranya suasana ruangan yang ber $\mathrm{AC}$, kondisi furnitur (kursi di bagian layanan internet), lampu kurang terang dan suara bising. Jarak fakultas dengan perpustakaan juga mempengaruhi kehadiran pemakai ke UPU Perpustakaan UGM. Dari penelitian diperoleh beberapa karakteristik pemakai yaitu: pemakai potensial UPU Perpustakaan UGM yang menggunakan teknologi komputer (baik penelusuran katalog dan internet secara keseluruhan) pada saat penelitian berlangsung adalah wanita sebanyak $56 \%$. Sedangkan statusnya sebagai mahasiswa (S1) semester 8 atau angkatan 2001 Fakultas ISIPOL 20,3\% jurusan Administrasi Negara, kedua Fakultas MIPA dan ketiga Fakultas Ekonomi. Berdasarkan asal/domisili pemakai dari luar Daerah Istimewa Yogyakarta 73\% yang lebih memanfaatkan teknologi komputer. Dan status perkawinan pemakai dalam penelitian ini, hampir semua pemakai khususnya mahasiswa $\mathrm{S} 1$ bersatus belum menikah 93\%.

Hasil penelitian menunjukkan $50-70 \%$ pemakai potensial (riil)(bukan pemakai maya/virtuil) mahasiswa yang datang ke perpustakaan untuk mencari bahan-bahan referensi yang digunakan oleh dosen mereka, termasuk bahan referensi untuk mendukung penulisan paper (tugas akhir), bahan bacaan perkuliahan, skripsi, penelitian dan hasil praktikum. Namun informasi tambahan pemakai maya pada bulan Agustus 2005 sebanyak 124.000 lebih menggunakan sarana internet untuk menelusur koleksi/informasi/jurnal/database online yang dilanggan UPU Perpustakaan UGM.

Pemakai teknologi komputer di UPU Perpustakaan UGM berdasarkan hasil kuesioner survei dan wawancara, ternyata $99 \%$ tidak ada yang "gaptek" atau gagap teknologi, artinya dengan kemajuan teknologi komputer pemakai tidak merasa canggung, untuk memanfaatkannya secara optimal.

Pemakai yang datang ke UPU Perpustakaan UGM terpenuhi kebutuhan informasi $66 \%$, sedangkan ketersediaan koleksi $75 \%$ sesuai dengan studi sebanyak 44\%. Ketersediaan unit komputer untuk penelusuran dan internet merata $15 \%$ di tiap unit layanan. Pemakai program S1 yang mengetahui adanya jaringan internet dan nirkabel sebesar $63 \%$, sedang informasi adanya jaringan internet dan nirkabel diperoleh dari teman sebesar 32,69\% dibandingkan dengan informasi dari dosen ataupun dari leaflet. Kecepatan akses menurut pemakai $67 \%$ menyatakan lumayan/sedang di bandingkan dengan jaringan yang ada di fakultas, sedangkan penggunaan komputer tidak antri $51 \%$, namun perlu diberi kursi untuk kenyamanan. Sikap petugas/pustakawan terhadap pemakai $81 \%$ sesuai harapan, terutama mahasiswa eksak $56 \%$ dan wanita $68 \%$. Jam layanan internet sudah cukup, namun pemakai menghendaki tetap di tambah jam layanan sampai pukul 21.00. Pemanfaatan jaringan internet $63 \%$ untuk mendownload dan mencari informasi, namun tidak menutup untuk mengirim e-mail dan chatting, bahkan ada yang main game. 
Perlunya dilakukan MONEV yaitu monitoring dan evaluasi bagi manajerial, karena UPU Perpustakaan memiliki keunggulan diantaranya $36 \%$ sarana komputernya, dan $35 \%$ koleksinya di bandingkan dengan di fakultas dan jurusan. Hal ini akan membantu Tim Manajerial UPU Perpustakaan UGM untuk meningkatkan layanan di masa datang

\section{DAFTAR PUSTAKA}

Astuti, Mary, Suyitno dan Dian Paramita, (1997). Studi jender profil sarjana di kota Yogyakarta. Yogyakarta: Pusat Studi Wanita UGM.

As'ad, Moh, ; Santhoso, Fauzan Heru dan Helmi, Avin Fadhilan, (1990). Interaksi sosial warga asrama mahasiswa daerah dengan masyarakat di sekitarnya kasus beberapa asrama mahasiswa Daerah di Daerah Kota Madya Yogyakarta. Yogyakarta: Fakultas Psikologi UGM.

Brown, Sally; Bill Downy; Phil Race, (1997). 500 Tips for Academic Librarians. London, Library Association Pub.

Buku Panduan, (2003). UPT Perpustakaan UGM, Yogyakarta:UPT Perpustakaan UGM.

Bungin, Burhan, (2003). Analisis Data Penelitian Kualitatif: Aktualisasi Metodologis ke Arah Ragam Varian Kontemporer, Ed.1., Cet.2, Jakarta: PT RajaGrafindo Persada.

Department for International Development (DF1D).(2003) Monitoring \& Evaluasi: sebagai Media Belajar Bersama dari Pengalaman, Yogyakarta, Universitas Gadjah Mada.

Dougherty, Richard M.(1978). Campus Document Delivery systems to serve Academic Libraries. Journal of Library Automation. 2(1): 124-131.

Hadi, Umar. (2004). Pengantar Otomasi Perpustakaan, Jakarta: Diklat Pustakawan
Tingkat Terampil Perpustakaan Nasional Republik Indonesia.

Hickey Thomas.(1979). Automatic Detection of Duplicate Monograph Records. Journal of Library Automation. 12(2) : 125-142.

Huda, Nuril, (1994). Manajemen Pelayanan Pengguna: pada Lokakarya Manajemen Perpustakaan perguruan Tinggi se Indonesia. Tanggal 6-7 September 1994 di Denpasar, Bali. Jakarta : Direktorat Jenderal Pendidikan Tinggi, Departemen Pendidikan dan Kebudayaan Proyek Pengembangan Staf dan Sarana Perguruan Tinggi(P2S2PT). IBRD Loan No. 3311-1ND.

Lancaster,F.W and E.G.Fayen. (1973). Information Retrieval On-Line, Los Angeles: Melville

Limb, Peter. (2004). Digital Dilemmas and Solutions, Oxford. Chandos Publishing.

McGill, Lou. (2002) Global chat: Web-based enquiries at the University of Laicester, dalam Libraries Without Walls 4: the delivery of library services to distant users, London: Facet Publishing.

Paul, Sandra K. Computers, Libraries and the Book Trade: Trends in North America. Australian Academic \& Research Libraries, 16:185-191, 1985

Perpustakaan Nasional RI. (2001). Standar Perpustakaan Perguruan Tinggi Kategori $C$. Jakarta: Perpustakaan Nasional Rl.

Prihatin, S. Djuni. Perubahan Perilaku Pemakai Perpustakaan dalam Seminar Nasional Perpustakaan dan Perubahan Perilaku Pemakai, UPT Perpustakaan UGM di Gedung Seminar FISIPOL UGM, 2 Maret 2002.

Priyanto, Ida Fajar. Membangun Citra Melalui Pelayanan Prima dalam Think, Tank for a: Community Development, Education Development, Library Development, kerjasama McGill University dan IAIN Syarif Hidayatullah, 14-16 Juni 2002. 
RESTRA Perpustakaan Universitas Gadjah Mada 2002-2006,6 April 2002

Rozaq, Abdul, Penyelenggaraan Penelitian dalam proses transisi menuju Universitas Riset dan PT BHMN: dalam Penjaminan Mutu Penelitian dan Pengabdian kepada Masyarakat: Prosiding Lokakarya Kebijakan dan Jaminan Mutu Bidang Penelitian dan Pengabdian Kepada Masyarakat Universitas Gadjah Mada 15 Desember 2003. Yogyakarta: Kantor Jaminan Mutu UGM, 2003.

Sevilla, Consuelo G... (et. Al), 1993. Pengantar Metode Penelitian, Jakarta : Penerbit Universitas Indonesia(UI-Press).

Slater, Margareth, (1990). Research Methods in Library and Information Studies, London, Library Association

Sulistyo-Basuki.(1993). Pengantar Ilmu Perpustakaan. Jakarta: Gramedia Pustaka Utama.

Toffler, Alfin. (1990). Gelombang Ketiga buku I dan II. Jakarta: Pantja Simpati.

Uminurida S. dan Lilik K Uswah. Reportase Internet sarana mendapatkan informasi dalam Media Informasi, Yogyakarta. UPT Perpustakaan UGM, 13 (41) 2000

Whitaker J. Sally. Computers, Libraries and the Book trade: European Trends. Australian Academic \& Research Libraries, 16: 185 $191,1985$.

Wilson, John H, 1977. Librarian introverted or integreted in The Australian Academic and Research Libraries Vol.8, no. 2 p.87-92 